\title{
In search of income reference points for SLCA using a country level sustainability benchmark (part 2): fair minimum wage. A contribution to the Oiconomy project
}

\author{
Pim R. Croes ${ }^{1}$ (D) Walter J. V. Vermeulen ${ }^{1}$ \\ Received: 10 November 2014 / Accepted: 21 December 2015 /Published online: 28 January 2016 \\ (C) The Author(s) 2016. This article is published with open access at Springerlink.com
}

\begin{abstract}
Purpose This paper is part 2 of our twin articles on income reference points for social life cycle assessment (SLCA). The purpose of this article is to provide a well-founded fair minimum wage standard, which enables the determination of the preventative costs for the impact category of unfair prices for labour in preventative costs-based SLCA.

Methods A five-step procedure was followed, comprising of (1) definition of the impact category and characterization factor, (2) a literature survey on standards and practices on fixing of minimum and living wages, (3) our proposal of a fair minimum wage based on the principles set in ILO conventions, the $\$ 2$ World Bank moderate poverty line and a country level benchmark, (4) a literature study on current sub-fair wages and (5) a proposal of how to use the findings. For justification of the results, the results were compared with other systems and tested the sensitivity of the results to changes in the composition of the benchmark group of countries.

Results and discussion Because literature showed that an absolute minimum wage is only suited for the lowest-income countries and relative minimum wage only for higher income countries, this paper proposes a relative system, bottom cutoff by an adjusted absolute minimum wage. The mean proportion
\end{abstract}

Responsible editor: Alessandra Zamagni

Electronic supplementary material The online version of this article (doi:10.1007/s11367-015-1017-1) contains supplementary material, which is available to authorized users.

Pim R. Croes

p.r.croes@uu.nl

1 Copernicus Institute of Sustainable Development, Utrecht University, Heidelberglaan 2, 3584 CS Utrecht, The Netherlands of the minimum wage of the gross national income (GNI) per capita in a benchmark group of the top $20 \%$ performing countries in the Sustainable Society Index-Human Development, is used as the relative principle for a fair minimum wage. The proposed absolute minimum wage is based on the 2005 World Bank \$2 (PPP) poverty line. The proposed relative system, based on 2011 data, is $44.4 \%$ of a country's GNI per capita and the proposed absolute minimum wage is $\$ 1547$ (PPP) per year and \$0.830 (PPP) per hour.

Conclusions A well-founded set of fair minimum wage targets is proposed for 183 countries to be used in SLCA and beyond. We also propose to use the difference between actual payment and a target determined according to the here presented methods as the measure in preventative costs-based LCA, such as the EcoCost system and the Oiconomy system.

Keywords ESCU · Fair wage · Minimum wage · Oiconomy · Poverty $\cdot$ Social LCA $\cdot$ Standard $\cdot$ Sustainability

\section{Introduction}

There is little doubt that the issue of sub-fair remuneration of labour and products should be included in SLCA. The UNEP/ SETAC guidelines for SLCA of products states: "development of a "meaning" database, which would include the necessary data for interpretation (e.g. minimum wage and livable wage by country) would represent a major advancement for SLCA practice" (UNEP and SETAC 2009), and various authors discuss the income issue in SLCA (e.g. Feschet et al. 2013; Norris 2006; Neugebauer et al. 2014). Neugebauer et al. consider a fair minimum wage as a key pathway to addressing social wellbeing and social justice in social life cycle assessment (SLCA) and propose to use ILO 
conventions and the living wage as starting points, which proposal we will elaborate in this article.

(Parent et al. 2010, p. 167) distinguish type 1 and type 2 SLCA. Type 1 SLCA uses performance reference points (PRPs) "to help understand the magnitude and significance of the collected data". In current impact-based type 1 SLCA, data and PRPs are at best used for qualitative assessment or nominal quantitative point systems (e.g. Hsu et al. 2013). Type 2 SLCA seeks cause-effect impact pathways to quantitatively link a factor to one of the endpoint indicators. However, because impact pathways related to income issues are extremely complex and reach far into the uncertain future, it will be quite a challenge to present an accurate pathwayderived measure for sub-fair wages.

However, preventative costs-based SLCA is an interval quantitative assessment without the need for cause-effect pathways. Part one of our twin articles on income standards (Croes and Vermeulen 2016) gives a short introduction on the principles of the preventative costs-based EcoCost LCA system (Vogtländer et al. 2000) and the Oiconomy system (Croes and Vermeulen 2015). We will here limit ourselves to a very short explanation of the most important concepts.

In preventative costs-based LCA, not the impact is the (un)sustainability measure, but the costs of preventing the impact. The measure is therefore independent of impact pathways and the perception of the seriousness. The EcoCost and Oiconomy systems weight issues by the preventative costs based distance to a target or PRP. The EcoCost system is a conventional LCA system, intended for comparative assessment and limited to environmental issues. It uses predetermined marginal preventative costs, which are the costs of the last (most expensive) employed available measure necessary to globally reach the target (assuming that the cheapest measures are employed first). The Oiconomy system follows the supply chain, copying the gradual price build-up for the hidden preventative costs of complete products. It allows for using product-specific onsite verified preventative costs and only uses the predetermined marginal costs as default values.

For preventative costs-based LCA, concrete targets (or PRPs) are an absolute requirement. Currently missing still is a method for setting concrete PRP for "a fair minimum wage". In this article, the fair minimum wage will be based on the market consisting of "Oiconomy consumers". This is a consumer that requires a damage-free product as a quality aspect of the product and is willing to pay the required extra costs for that quality.

The goal of this part 2 article is to provide a fair minimum wage standard, which enables the determination of the preventative costs distance to target, in the Oiconomy system expressed in "Eco Social Cost Units" (ESCU), for the impact category of unfair prices for labour in preventative costs-based SLCA.

\section{Methods}

For the determination of the marginal preventative costs for the impact categories of unfair prices for labour in preventative costs-based SLCA, the following procedure was followed, derived from the EcoCost method and equal to the Oiconomy method, in five steps:

1. Definition of the impact category and characterization factor.

2. Determination of the fair minimum wage target of reference point.

a. Literature assessment of international standards, discourse and practices on poverty, minimum wages and living wages.

b. Proposal of a fair minimum wage based on available international standards and a country-level benchmark.

3. Listing of available preventative measures, ranked by costs with lowest on top.

4. Determination of the costs of the available preventative measures.

5. Assessment of which preventative measures are required to globally reach the target.

6. The last and most expensive determined this way presents the marginal preventative costs.

In Section 3.1 (step 1), we present our definition.

In Section 3.2 (step 2a), we review current standards, conventions and debates on the concept and measurement of poverty and the practice of minimum wages and living wages and we discuss the pros and cons of the various approaches.

In Section 3.3 (step 2b), based on our findings and the fact that there is no universally applicable method for fixing a minimum wage, we present our alternative methods allowing the determination of fair minimum wages for every country and provide justification by comparison with other methods. Given the different outcomes for the various systems in lowincome and high-income countries, we apply a system based on two principles: an adjusted absolute value on the lower side and a relative value on the higher side. We then also need to have good grounds to identify the threshold point for both approaches. First, we will explain the lower side then the threshold point and finally the higher side. We propose a method based on the available internationally agreed conventions on human rights and labour conditions and on the minimum wage practices in a benchmark group of the $20 \%$ top performing countries, using a benchmark group, earlier proposed by (Croes and Vermeulen 2016). Thereafter, a concrete fair minimum wage could be proposed for 183 countries as PRP in SLCA in general. 
In Section 3.4 (steps 3, 4 and 5), with a set definition and standard for fair payment, we describe how the difference between the found reference point of the fair minimum wage and the actually paid sub-fair wage can be used for the determination of ESCU's as a measure of (un)sustainability in preventative costs-based SLCA. For this purpose, we investigate literature on the level of currently paid sub-fair wages.

\section{Results}

\subsection{Impact category and characterization factor (step 1)}

The impact category is product-related poverty, characterized by underpaid dollars or other currencies, and the target to keep the worker, either company- or self-employed, and his family, out of poverty.

\subsection{International standards, discourse and practices (step 2a)}

\subsubsection{Poverty and fair payment}

The right to a fair remuneration for a worker and his family has been agreed upon in a range of international conventions and translated into national regulations. Anker gives an excellent overview of living wage conventions (UN, American and European), national constitutions, major ILO documents, NGOs and corporations' position papers and statements (Anker 2011).

Article 25.1 of the United Nations Universal Declaration of Human Rights of 1948 states: "Everyone has the right to a standard of living adequate for the health and well-being of himself and of his family, including food, clothing, housing, medical care, necessary social services, and the right to security...", and article 23: "everyone who works has the right to just and favourable remuneration ensuring for himself and his family an existence worthy of human dignity" (UN General Assembly 1948).

Summarizing, article 25.1 states that nobody should be in poverty and article 23 asserts that work should be an adequate means to provide a secure life and to prevent poverty.

The preamble to the ILO constitution notes that peace and harmony in the world require "the provision of an adequate living wage" (ILO 1944). The 2008 ILO Declaration on Social Justice for a Fair Globalization, building on earlier 1919 and 1944 declarations and concerning the aims of the ILO, emphasizes its obligation to develop and enhance "policies in regard to wages and earnings, hours and other conditions of work, designed to ensure a just share of the fruits of progress to all and a minimum living wage to all employed and in need of such protection", in this way addressing the issue of inequality (ILO 2008, p.10). The right to a minimum wage was further formalized in ILO conventions in 1928, 1951 and 1970.

Poverty reduction is one of the most important United Nations' Millennium Development Goals (United Nations 2007, p. 21) and one of the primary objectives of the World Bank.

These conventions and statements demonstrate international agreement on the right to a decent minimum wage. In practice, however, apart from the fact that the minimum wage is widely disrespected and poorly enforced, statutory minimum wages of many countries are below a living wage (definition below).

The conventions all agree on the right to a fair remuneration for the worker and his family.

However, wordings utilized are vague, like "decent", "favourable", "worthy of", "adequate", "basic needs" and "just". Also national constitutions remain vague, although they sometimes add statements, like: "Equal pay for equal work" (USA), "Maintaining a certain purchasing power" (Brazil), "Share of social enjoyments of cultural and social opportunities" (India, Namibia) and "Sufficient for the education of the families' children" (Mexico) (Anker 2011, pp. 67$83)$.

ILO conventions define requirements on working hours, overtime, collective bargaining systems and labour conditions, but also remain vague in their wordings on the level of the minimum wages.

Various NGOs like Ethical Trading Initiative 2012 (ETI), Social Accountability International 2008 (SAI), Fair Labor Association 2011 (FLA) and Global Social Compliance Programme 2010(GSCP) tend to follow ILO conventions and include requirements on work hours, information, collective bargaining systems, financial disciplinary measures, subcontracting, fixed term contracting, labour conditions, paid leave arrangements and other arrangements. However, none of these NGOs has a clear definition of the living wage.

Companies publish position papers and comments on their responsibility. Many support the concept of the living wage, but also lack a proper measurement and of a concrete definition as an excuse for not executing their aspirations (Anker 2011, pp. 7,8). Many pay statutory minimum wages, even if these are lower than a living wage. Some state that it is not them but governments who are responsible for setting the minimum wage at a proper living wage or that minimum wages should be determined by negotiations between workers and management, which is understandable for reasons of competition.

We conclude that supranational conventions and NGOs agree on the need for a minimum wage based on the living wage but are very vague in their definitions and lack concrete criteria. Companies and countries support the living wage in words but are lacking a concrete common definition. Fierce competition and fear of capital relocation make countries to 
set their minimum wages below and sometimes far below a living wage. No properly enforced minimum wage system exists that globally eliminates competition below a fair threshold level.

Various authors describe the pros and cons of establishing a minimum wage (Neumark and Wascher 2007; Rutkowski 2003; Wu and Liu 1999; Haughton and Khandker 2009). Frequently mentioned arguments in favour are the following:

- Providing a worker and his family with their needs for a decent minimum standard of living

- Prevention of exploitation of workers by employers

- Reduction of inequality and a fairer wage structure

- Stimulation of the economy because low-income families spend a higher percentage of their income than highincome families

- Stimulus for business to continuously increase technical efficiency

Frequently mentioned arguments against are the following:

- Higher unemployment due to relocation of jobs to locations with lower wages and to automation and reduction of the country's competitiveness. However, the author also notes that this effect is not valid for moderate minimum wages (Rutkowski 2003, p. 12).

- Minimum wages in the current economy are not an efficient means to reduce poverty because the majority of families in poverty are not workers (Rutkowski 2003, p. 12).

- Excessively high minimum wages may lead to a high noncompliance problem and increase the shadow economy (Rutkowski 2003, p. 7).

- Fear of economic decline.

A great majority of countries has set a statutory minimum wage system, and in some developed countries, a wellfunctioning bargaining system between employers and employees has achieved a working minimum wage system without statutory regulations (e.g. Norway). However, many countries have set their minimum wage below a living wage (Anker 2006a).

Causes of poverty are manifold, including poor education, poor social care and governance, family size, corruption and violence, exploitation of workers, unfair pay, climate change, ethnic or gender discrimination, living in a remote area and debt problems. Most people in poverty deal with at least one of the following four situations: unfair wages, unfair prices for their manufactured products or services, unemployment and self-employment insufficient for subsistence. Therefore, poverty can only be effectively addressed if (preferably) all four of these conditions are addressed together without repercussions on each other. The issues of competition and the comprehensive measurement of these issues can be addressed in the Oiconomy system, in which the Oiconomy consumer requires evidence, based on certification, with onsite verification, as proposed by (Croes and Vermeulen 2015).

What we need for preventative costs-based SLCA, aiming to reveal the hidden costs for the issue of fair wages, is a target, or PRP, for determining the cost distance to a fair wage. There are two major ways determining such target: from the point of view of absolute poverty and of relative poverty.

\subsubsection{Absolute poverty}

There is extensive literature on poverty and its measurement, e.g. by the World Bank and the ILO (Haughton and Khandker 2009; Ravallion 1992, 2011; World Bank 2005; International Training Centre of the ILO 2008). The World Bank regularly publishes progress reports on global poverty, e.g. (Chen and Ravallion 2008, 2012). This paper will limit itself to a summary of poverty-related issues relevant to the purpose of the creation of a standard for fair remuneration.

Basically, two types of poverty are distinguished: absolute poverty and relative poverty and two main concepts of wage thresholds have been widely discussed: the minimum wage and the living wage.

Absolute poverty and the therefrom derived living wage are usually measured by the costs of a basket of basic needs of a person. However, an abundance of researchers has demonstrated that living wages differ by country, culture, development level, region and even by town, arguing that it is impossible to set one universally applicable and fair global minimum wage (Anker 2006a, b, 2011; Belser and Sobeck 2012; Boeri 2009; Brenner et al. 2002; Ravallion 2010). Even within the group of high-income countries, it is difficult to use one and the same poverty line because food choices, prices, cultures and climate conditions vary greatly. The World Bank solves the price issue by the use of the purchase power parity (PPP) which compares what people in the different locations can buy with their local currency with the value of one US\$ in a set reference year. Different food choices are covered by looking at the local foodstuffs required for a minimum caloric intake (Haughton and Khandker 2009; Ravallion 1992).

Relative poverty relates to the ability to function in a certain community and is usually measured as a proportion of the national income. It will be discussed in a separate section below.

\subsubsection{Living wage}

The concept of the living wage also varies amongst the different authors, some relating the living wage to absolute poverty and others to relative poverty. 
Anker relates the living wage to absolute poverty by his definition: "the poverty line is the income necessary for a household to afford a low-cost nutritious diet and non-food necessities at levels considered acceptable in a given country; the living wage is the hourly wage rate required to support a household at the poverty line" (Anker 2006a, p.312). The words "necessities" and "acceptable", however, remain open to interpretation, and the definition includes fewer elements than the earlier cited human rights principles.

The NGO 'Labour Behind the Label' goes a little further and defines the living wage as "one which enables workers to meet their needs for nutritious food and clean water, shelter, clothes, education, healthcare and transport, as well as providing a discretionary income. It should take into account the cost of living, social security benefits and the standard of living of others nearby". By the inclusion of the standard of living of others, this NGO defines the living wage as to prevent relative poverty (Labour Behind the Label 2013). The latter is more in line with Human Rights article 22, stating: "everyone, as a member of society, has the right to social security and is entitled to realization, through national effort and international cooperation and in accordance with the organization and resources of each State, of the economic, social and cultural rights indispensable for his dignity and the free development of his personality" (UN General Assembly 1948).

Although at present, there is neither a generally accepted definition of what a living wage is nor a generally agreed methodology on how to measure it, the World Bank poverty statistics are based on a global poverty line. Based on the average of the national poverty lines of the 15 world's poorest countries (Ravallion et al. 2008, p. 16), determined by the method of a basket of basic needs, the absolute poverty line was set at $\$ 1.25$ (2005 US\$ PPP) per person per day. People living below this line are considered in extreme poverty. Increasingly, the World Bank uses \$2 (2005 US\$ PPP) as moderate poverty line, determined as the median of the poverty line of all (75) developing countries (Ravallion et al. 2008). However, Pritchett argues that this $\$ 2$ has not much justification (Pritchett 2006, p. 2). Some authors describing shortcomings of the World Bank's absolute poverty lines propose to use a range of poverty lines. Concluding, the World Bank's \$2 moderate poverty line is unfit for universal application, but, preferably with some better justification, may be useful for setting the very bottom global threshold for our purpose.

\subsubsection{Relative poverty}

Analysis of relative poverty shows that poverty occurs not only in low-income countries, but also in other countries, even though their bottom wages are far above the World Bank poverty lines. Even in most developed countries, minimum wages are regularly below the living wage (Belser and
Sobeck 2012; Gentilini and Sumner 2012) and there is a clear trend of increasing poverty in middle-income countries (Sumner 2010, 2012).

The ILO's Minimum Wage Fixing Convention (No. 131), 1970 , sets six criteria for determining the level of a statutory minimum wage (ILO 1992): the needs of workers and their families, the general level of wages in a country, the cost of living, social security benefits, the relative living standards of social groups and economic factors such as economic development and maintenance of employment. Relative poverty is usually measured in a far more simple way than absolute poverty as a proportion of the mean or median income or consumption.

The definition for relative poverty given by the European Union is: "People are said to be living in poverty if their income and resources are so inadequate as to preclude them from having a standard of living considered acceptable in the society in which they live." (Council of the European Union 2004, p. 8). Most Organisation for Economic Co-operation and Development (OECD) countries use the median income as an indicator for poverty and the OECD uses the indicator of $60 \%$ of the median income as the "risk-of-poverty" rate (Atkinson et al. 2004, p. 55; ILO 2010).

The European Commission states: "the proportion of individuals living in households where equivalized income is below the threshold of $60 \%$ of the national equivalized median income is taken as an indicator of relative poverty" (Council of the European Union 2004, p.13).

The European Trade Union Confederation recommends "that the effective national minimum wage should be at least equal to $50 \%$ of the average wage, or $60 \%$ of the median wage" (ETUC 2012, p. 8).

Ravallion (World Bank) points out that measured by the use of the mean or median, poverty is not reduced by economic growth (Ravallion 2010, p. 17). However, the relative method seems very useful for the determination of a fair wage that does not necessarily need to be the poverty line because it deals with inequality and has a direct relation to the size of the available cake to be shared by a country's population.

Sweat Free Communities uses a constant percentage of the GDP per capita as the living wage (SweatFree Communities 2014). This NGO takes the USA national minimum wage + $20 \%$ as a starting point and applies the proportion of the obtained living wage relative to the USA GDP per capita for all countries, ignoring the fact that by this method, living wages become unrealistically low in very poor countries (Anker 2011, p.43).

The ILO's Global Wage Report 2008/09 shows that countries, with data on mean wages available, most frequently set their minimum wages at between 35 and $45 \%$ of mean wages. "In the smaller set of countries for which data on median wages are available, the minimum wage is most frequently 
set at about $50 \%$ to $60 \%$ of the median wage" (Belser and Sobeck 2012, p. 122).

Mentioned advantages of a consistently executed relative poverty-based system over an absolute system are the following:

- It better addresses inequality and the responsibility of governments to fairly distribute the national income.

- It avoids complex calculations of living wages, which will always be inaccurate (Pritchett 2006, p. 7).

- It better addresses automatic adaptation to the cost of living and its development in a country (Ravallion 2010, p. 15)

- It better addresses the costs of social inclusion (Ravallion 2010, p. 15).

Disadvantages are the following:

- It leads to unacceptably low minimum wages in developing countries (Anker 2011, p.43; Ravallion 2010, p. 17).

- It does not give the possibility of addressing differences within countries, such as between rural and urban costs of living.

- It does not address individual- or country-specific family sizes and women's participation.

Typical examples of the absolute and relative measurement are demonstrated by the different approaches of the USA and the EU. The USA has set an absolute minimum wage. Because it is not regularly adjusted to rising living costs, the USA now has a minimum wage below the living wage (Luce 2012). The EU has taken the approach of a poverty line at $60 \%$ of the median income (Council of the European Union 2004, p.14).

\subsection{Determination of the fair minimum wage target (step 2b)}

\subsubsection{Fair minimum wage}

The living wage is the wage keeping a worker and his family out of poverty and may be considered a direct consequence of human rights (UN General Assembly 1948, article 22, 23, 25, 26).

The minimum wage is a more political instrument and ideally should not be below the living wage. However, most lowincome countries simply do not have the means to set their minimum wages at this level and high-income countries and emerging middle-income countries also tend to keep their minimum wages low, for reasons of competition. Data and comparison of living and minimum wages, including their calculation methods, demonstrating this observation, are reported by (Wage Indicator 2013) and by (Anker 2006a).

This raises the question of what would then be a fair minimum wage. One could argue that a minimum wage set at living wage level, even if that is based on the poverty line of $\$ 2$ per person per day, is a fair wage in low-income countries that do not have the means for a higher minimum wage. However, for a product destined for a high-income country and for an Oiconomy consumer, one could also argue that the relevant means are available.

Another way is to take the relative point of view and look at the relation between a country's minimum wage and its gross national income per capita $\left(\mathrm{GNI}_{\mathrm{Cap}}\right)$.

In order to be able to set target values and to compare values with a benchmark, the average of the $20 \%$ best performing countries is proposed as a norm. For this purpose, Croes and Vermeulen 2016 proposed a benchmark group of the $20 \%$ best performing countries in the Sustainable Society Index Human Wellbeing (SSI HW) (van de Kerk and Manuel 2012).

The average percentage of the minimum wage relative to the $\mathrm{GNI}_{\text {Cap }}$ (in PPP) of all countries in a group of 149 countries with statutory minimum yearly wage is $54.1 \%$. The benchmark group has an average percentage of $44.4 \%$, and 26 countries have unrealistic percentages of over $80 \%$ and 18 countries of even over $100 \%$. Figure 1 shows how the minimum wage/(GNI $\left(\mathrm{Gap}_{\mathrm{Cap}}\right)$ percentages of the benchmark group of countries relate to the total group, and Appendix 1 (Electronic Supplementary Material) shows the statutory minimum wages of all countries.

Various large emerging countries keep their minimum wages relatively low. China has a percentage of about $17 \%$ (measured by the lowest minimum wage of China's provinces), Indonesia $27.2 \%$, Vietnam $36.2 \%$, Mexico $12.0 \%$, Brazil $31.6 \%$ and South Africa $33.5 \%$. But the USA also has a very low percentage of $30.9 \%$, far below the high-income countries' average.

India, the country with the highest contribution to global poverty, has a very complex and poorly enforced system of 1171 different minimum wages, depending on location, industry sector and companies. Also, other developing countries in Asia, Africa and Latin America tend to have multiple and poorly enforced minimum wages, whereas developed countries usually have better enforced national minimum wages (Rani and Belser 2012). Their low labour costs help lowincome countries develop, which seems fair for the country as a whole, but not for the affected sub-living wage workers, and because such countries usually show high and rising inequality and corruption, the fairness of the distribution of the new wealth is questionable.

In both cases of countries with minimum wages set above their abilities and those with low percentages, it is clear that, in setting the minimum wage, political considerations play an important role, limiting the achievement of a fair minimum wage.

From our literature review, we conclude that there is no agreed international system or standard available for the determination of a fair minimum wage. No universally applicable absolute fair minimum wage can be determined for both 
Fig. 12011 PPP minimum wage percentage of GNI per capita (World Bank 2011 PPP) per country. Minimum wages obtained most from OECD Stat 2012, data on 2011; ILO Ilostat 2012, data on 2011, and where not available from minimumwage.org and wageindicator and for Bangladesh and Taiwan from Fairwear and Taiwan Congress Library

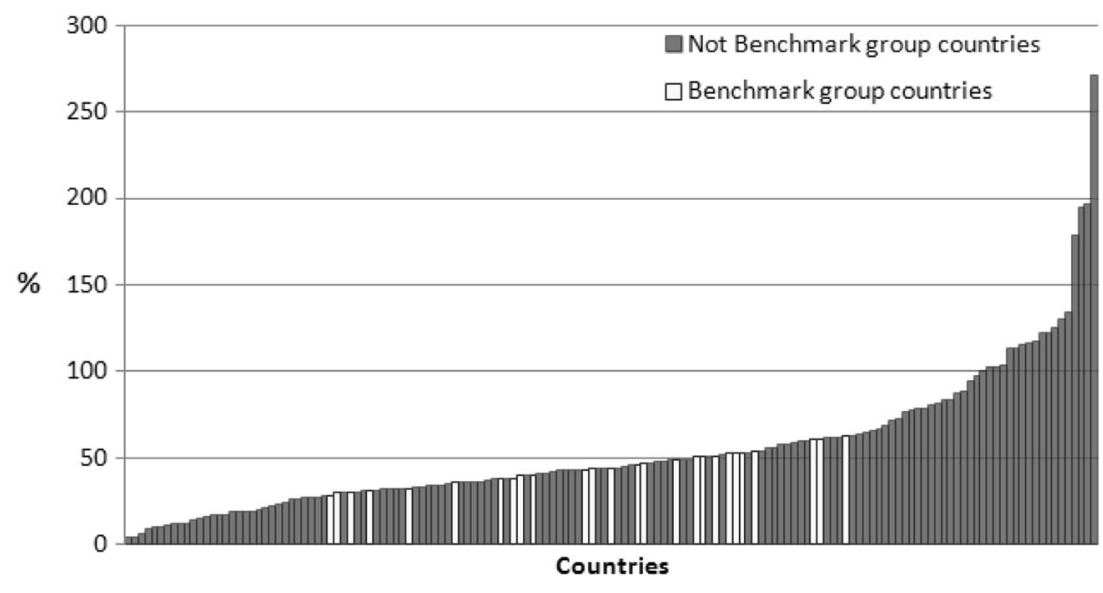

low- and high-income countries. A consistent relative system would lead to unacceptably low minimum wages in the lowest-income countries. Already in 1992, Ravallion argued that poverty measurement using a dual system of both a relative and an absolute poverty line would be a straightforward method for poverty measurement (Ravallion 1992, p. 35), but the idea was not elaborated. Likewise, we now propose to use the relative method bottom cutoff by an absolute minimum for low-income countries, not only as a target for the Oiconomy system but also as a PRP in SLCA in general and even outside the field of applying LCA.

\subsubsection{Determining the absolute minimum wage}

For the proposal of a fair absolute minimum wage, we need to consider the number of working hours, family size, labour participation and the poverty line. In practice, various approaches make arbitrary choices and sometimes only look at a part of the issue. We suggest that by integrally addressing working hours, family size, labour participation and the poverty bottom line, we can justify a fair Absolute Minimum Wage as the bottom line.

\subsubsection{Working hours and days}

The ILO C047-Forty-Hour Week Convention in 1935, ratified by 15 countries, agreed on the principle of a 40-h working week (ILO 1935). The ILO recommendation 116 of 1962 states (summarized): "Each member should promote and, where possible, ensure the application of the principle of the progressive reduction of normal hours of work with a view to attaining the 40 hour week, without any reduction in the wages of workers: and "where the duration of the normal working week exceeds 48 hours, immediate steps should be taken to bring it down to this level, without any reduction in the wages of the workers" (ILO 1962).

The ILO C132-Holidays with Pay Convention, 1970, ratified by 36 countries, states: "Every person to whom the convention applies is entitled to an annual paid holiday which shall in no case be less than three working weeks for one year of service", and "public and customary holidays are not counted as part of the minimum annual holiday with pay of three weeks" (ILO 1970).

The ILO conventions agree on a standard work week of $40 \mathrm{~h}$, a maximum of $48 \mathrm{~h}$ and also on a maximum of 49 work weeks, on paid public holidays and on a standard work day of $8 \mathrm{~h}$. The average number of public holidays in 62 countries as collected by Mercer is 12 days (Mercer 2011). Therefore, an ILO conventions-derived standard for a working year can be calculated as $(49 \times 40)-(12 \times 8)=1864 \mathrm{~h}$ and as $1864 / 8=233$ work days.

In practice, it seems very difficult to maintain these conventions. Only 15 countries ratified the 40-h week convention. Many low- and middle-income countries and even most NGOs and the Asia Floor Wage Alliance use $48 \mathrm{~h}$ as a maximum work week. Based on a 48-h week and the ILO agreed holiday system, a standard work year would consist of $2237 \mathrm{~h}$. The yearly work hours in 2012 in OECD countries varied from $1381 \mathrm{~h}$ (Netherlands) to $2226 \mathrm{~h}$ (Mexico). In 2012, the OECD average was 1766 h (OECD Stat Extracts 2012). USA living wage calculations are based on 2080 h/year (Luce 2012, p. 13-14). Not all of the variation is due to different perceptions of what a standard work week should be. Labour participation rate, voluntary parttime work in developed countries and other cultural differences heavily influence the average work week. For a measuring method, an absolute minimum must be based on one and the same number of working hours, where possible, based on international agreements. Therefore, we propose to use the above described ILO derived 1864-h work year.

\subsubsection{Family size}

The discussion on family size is a morally difficult one. "The minimum wage should allow the worker and his family an acceptable standard of living" (Anker 2006a). The principles of "equal pay for equal work" (UN General Assembly 1948, 
article 23) and "a wage should allow an acceptable standard of living" are somewhat contradictory. Some religious and cultural practices oppose birth control. In practice, low birth control increases the risk of poverty, although low-income families tend to receive assistance from their social networks (Edin and Lein 1997, p. 258). Because population growth is a major sustainability threat, it seems reasonable to base family size on a more or less constant population size with 2 births per woman.

Systems have been developed for the number and weighting of family members, by which household size is defined in terms of "adult equivalents". In the scale used by the World Bank and the OECD, the first adult in a family counts as one adult, the second adult counts as 0.7 adults and children are given a weighting of 0.5 . In this scale, a family of two adults and two children is counted as a family size 2.7 adult equivalents (World Bank 2005, p.34).

The Asia Floor Wage Alliance, a joint effort of Asian labour unions, determined their absolute floor wage based on a family of $2+2$ persons, while counting children as 0.5 adult, resulting in three adult equivalents for a standard family (Bhattacharjee and Roy 2012, p. 78).

\subsubsection{Labour participation}

According to Anker, there is no consensus in the assumption of the number of income-providing family workers. Anker gives an overview of 13 methods and assumptions, which vary from one to two full-time providing workers per family. Not only cultural aspects and the level of development but also the unemployment rates all influence labour participation levels in practice. In Anker's opinion, 1.5 workers is a good assumption (Anker 2011, p. 47), but he is clear on the poor substantiation of this assumption. The Oiconomy consumer enables market players to prevent unfair pay, but does not interfere with actual choices and practices. Parents provide for their children and children for their elderly parents, either directly via family or community care or via institutional systems such as pensions, healthcare and education subsidies. How countries organize this is the responsibility of their politicians.

Following this logic, a very simple system can be applied, combining the aspects of family size and labour participation. The average life expectancy (LE) at birth in our benchmark group of countries is 78.34 years, and the average number of working years in these countries is 46.21 years. This means that on average in his working life, every person has to gain $78.34 / 46.21=1.70$ times a living income (the number of working years was calculated as the mean retirement age minus 18 years, which for the minimum wage purpose is reasonable because longer education commonly leads to higher incomes). However, the raising of children prevents at least one of the parents from raising a full income. It is remarkable that almost all authors discussing the labour participation rate in relation to setting the minimum wage base their methods on a family situation, neglecting the full lifetime of people, although that is partly compensated by weighting children as 0.5 adult equivalents.

With a family with two children, it seems reasonable to assume that one of the parents can only gain a half income, as Anker proposes, but only during half of the 46.66 working years. This means that, following the working years/life expectancy logic, the average worker has to gain the $25 \%$ lost income of one other person, which makes us propose a fair minimum wage of $1.70 \times 1.25=2.12$ times the living income for one person. Anker estimates average labour participation rates in 12 investigated countries at 1.27 (Anker 2006a, p. 322 ), very close to the above assumed factor of 1.25 .

\subsubsection{A World Bank poverty line-derived absolute minimum wage}

The World Bank proposes an absolute line for extreme poverty at $\$ 1.25$ and one for moderate poverty line (MPL) at $\$ 2$ (2005 US\$ PPP) per person per day (Ravallion et al. 2008). Because, according to the World Bank, below the line of $\$ 2$, people are still in poverty and the $\$ 1.25$ line cannot be considered "fair", we choose to use the \$2 line. This \$2 absolute poverty line needs to be translated into an absolute yearly minimum wage (AMW). Following the same logic as above for the required labour contribution to other people, a simple formula translating the MPL into an $\mathrm{AMW}_{\mathrm{y}}$ is: $\mathrm{AMW}_{\mathrm{y}}=(365 \times \mathrm{MPL} \times \mathrm{LCR} \times(\mathrm{LE} / \mathrm{WY}))$, where LCR is the labour contribution ratio, LE the life expectancy, and WY the working years. Using this formula with the averages of the benchmark group, the $\mathrm{AMW}_{\mathrm{y}}$ becomes: $365 \times \$ 2 \times 1.25 \times(78.34 / 46.21)=\$ 1546.96$ per year. Using the above derived standards for working hours and working days, this translates into an hourly AMW $\left(\mathrm{AMW}_{\mathrm{h}}\right)$ of $\$ 1546.96 / 1864=\$ 0.830$, a daily AMW $\left(\mathrm{AMW}_{\mathrm{d}}\right)$ of $\$$ $1546.96 / 233=\$ 6.64$ and a monthly AMW $\left(\mathrm{AMW}_{\mathrm{m}}\right)$ of $\$ 1546.96 / 12=\$ 128.91$, all in 2005 US\$ PPP. AMWs in current currencies must be multiplied by the exchange rate compared to the value of the 2005 US\$ PPP.

\subsubsection{Validity and comparison}

In 2014, the developers of the SSI changed the composition of the SSI HW because of limited availability of sub-indicators, with the consequence that some countries, including the USA, in our benchmark group fell out of our benchmark group. This gave us the opportunity to test the sensitivity of our proposed fair minimum wages to the composition of the group. We also tested the sensitivity to the benchmark size and against using a population-weighted averaging of country data instead of straight averaging. The results are presented in Table 1. 
Table 1 Sensitivity of AMWy (in US\$ 2011 PPP) and the average ratio $\mathrm{MW} / \mathrm{GNI}_{\text {cap }}$ to the country benchmark size, type of average and the inclusion of the USA

\begin{tabular}{lllll}
\hline Country index & Countries & Type of average & AMW $_{\mathrm{y}}$ & Average ratio MW/GNI cap \\
\hline 2013 HDI & 22 & Standard average & 1554 & 0.446 \\
2012 SSI HW & 26 & Standard average & 1545 & 0.442 \\
2014 SSI HW & 25 & Standard average & 1548 & 0.451 \\
2013 HDI & 22 & Population-weighted average & 1550 & 0.399 \\
2012 SSI HW & 26 & Population-weighted average & 1574 & 0.343 \\
2014 SSI HW & 25 & Population-weighted average & 1595 & 0.451 \\
2013 HDI & 16 & Standard average & 1564 & 0.458 \\
2012 SSI HW & 19 & Standard average & 1558 & 0.452 \\
2014 SSI HW & 18 & Standard average & 1552 & 0.458 \\
2013 HDI & 11 & Standard average & 1557 & 0.462 \\
2012 SSI HW & 13 & Standard average & 1543 & 0.458 \\
2014 SSI HW & 12 & Standard average & 1544 & 0.443 \\
\hline
\end{tabular}

$\mathrm{AMW}_{\mathrm{y}}$ is the proposed "absolute yearly minimum wage", MW is the minimum wage and $\mathrm{GNI}_{\text {cap }}$ the gross national income. The countries represent the countries with statutory minimum wage only
One can question whether this approach leads to extreme outcomes. We will now assess this issue by comparing our approach with other methods.

The Asia Floor Wage Alliance (AFW) advocates a global minimum wage based on the living wage (Bhattacharjee and Roy 2012; Merk 2009). The AFW determined the living wage for a group of Asian countries comprising Bangladesh, India, China, Indonesia, Thailand and Sri Lanka. The starting points for the AFW living wage are the costs of a basket of basic foodstuffs required for the intake of $3000 \mathrm{kcal}$ per day and three adult equivalents per family. Basing itself on "Engel's law", the AFW multiplies the obtained food costs with a factor 2 for non-food needs. Engel's law of consumption is the observation that as income rises, a lower percentage is spent on food. In high-income countries, food expenditures total less than $20 \%$ of family expenditures, but in low-income countries "well over $50 \%$ ", which percentage explains the factor 2 . For 2012, the AFW determined a living wage of $\$ 540$ (PPP) per month or $\$ 6480$ per year, which is more than four times the above calculated $\$ 2$ poverty line-based absolute minimum wage. Because the AFW chooses "not to lower the standard of any country", their starting point was set high. An average daily energy need of $3000 \mathrm{kcal}$ indeed seems far too high. A joint $\mathrm{FAO} / \mathrm{WHO} / \mathrm{UNU}$ report shows that these $3000 \mathrm{kcal}$ is true for quite active male adults, but is far lower for women, children and the elderly (FAO et al. 2001, p. 41-43). The Dutch Nutrition Centre gives an average for adults of $2250 \mathrm{kcal}$ (Voedingscentrum 2014). Three adult equivalents per worker are far more than the average factor of $2.12 \mathrm{calcu}-$ lated above. Correcting the Asia Floor Wage for these parameters gives a floor wage of $\$ 6480 \times(2250 / 3000) \times(2.12 /$ $3)=\$ 3434$. However, because three countries in the AFW research group (China, Thailand and Sri Lanka) do not belong to the very poorest countries, even this reduced value may still not be realistic for the poorest countries. Using this paper's methodology, these countries fall under the relative system. As presented later, the proposed minimum wage for China is \$3714, for Thailand \$3701 and for Sri Lanka \$2444, far closer to the here corrected AFW proposal.

Another method was developed by Anker for an estimation of the living wage (Anker 2006a). Like the Asia Floor Wage Alliance, he starts with expenditure for food requirements. But Anker adds non-food expenditures, which for low-income countries are estimated at about $30 \%$. Anker estimates the living wage in low-income countries at about $\$ 1.70$ per hour, which is double the above derived absolute minimum wage. However, Anker chooses to base his calculations on peak family sizes, the period in the life of an average family raising children and on actual family sizes.

Because the distribution of income over different life periods of a person and local labour participation customs is a private and local political responsibility and because the Oiconomy consumer cannot be expected to pay for unsustainable birth rate situations, also Anker's system is not suited for our purpose.

\subsubsection{The threshold: kink point theory}

Edward derives an "ethical poverty line" based on the "Preston curve". Various authors argue that it is not income but health and life expectancy (LE) that make the most important development indicator. Preston demonstrated that LE plotted against the GDP per capita (GDP/Cap) gives a logarithmic-looking curve, showing a sharp rise at low GDP/Cap and remaining almost constant at high GDP/Cap, the "Preston curve" (Preston 1975, p. 235). Deaton found that inequality is not the direct cause of this relation, leaving absolute poverty itself as a probable determining factor (Deaton 2003, p. 151). Also Wilkinson and Pickett (2009, p. 499) and Pritchett and Viarengo (2010, p. 3) describe this relation between income and LE. Pritchett and Viarengo (2010, p. 3) and 
Feschet et al. (2013) demonstrate that the relation is valid not only across countries but also for individual countries, although there is some time delay between the rising of the GDP/Cap and the increase in LE. In the SLCA community, the Preston curve is discussed as a possibility to determine a pathway between socio-economic factors and health (Bocoum et al. 2015; Norris 2006; Feschet et al. 2013).

The Preston curve may also be interpreted as having a kink point above which GDP/Cap point the LE hardly rises or in other words above which point more wealth hardly leads to more life years (Edward 2006). By mathematical analysis of the curve, Edward determined this kink point "somewhere between $\$ 2.70$ and $\$ 3.90$ per day" and proposes an "ethical poverty line" at $\$ 2.70$ per day in 2002 US\$ PPP. Visually, the Preston curve for the year 2011 shows three sections with two kink points. We added the linear trend curves to these sections and determined the intersections. The curve (Figs. 2 and 3) shows a rapid rise in LE with increasing GDP/Cap until approximately 68 years at a GDP/Cap of about $\$ 3500$, followed by a slow rise to 79 years at a GDP/Cap of about $\$ 30,000$ and remaining more or less constant from that point. In our benchmark group of the top $20 \%$ countries ranked by the SSI HW, on average, the statutory minimum wage is $42.7 \%$ of the GDP/Cap. Taking this $\$ 3500$ as a benchmark minimum wage would result in $0.427 \times \$ 3500=\$ 1495$, remarkably close to the World Bank \$2 based \$ 1547 as proposed above.

Feschet et al., however, describe the curve sharply rising up to a GDP/Cap of about $\$ 10,000$ and Norris of $\$ 5000$, quite different from our $\$ 3500$. These authors however do not discuss the curve from a kink point of view, but as a means to develop a pathway between socio-economic factors and health, one of the most important endpoint indicators in LCA. To investigate the validity of using the Preston curve as an indicator, in Fig. 4, we present a variation by plotting not life years against the GDP/Cap, but happy life years, LE multiplied with a happiness score
(Veenhoven 2012). If we want to see a kink point in this figure, it would be at a GDP/Cap of about $\$ 25,000$, a different location again. We will further discuss the implications of this in the discussion section.

\subsubsection{Determining the relative minimum wage}

Let us now look at the higher end of the income spectrum, where we will apply a relative value approach. As we saw in Section 3.2, a country's relative poverty line is usually measured by a constant proportion of an economic wealth indicator. In this section, the same benchmark group of countries as described in Section 3.3 will be used.

A relative minimum wage needs a constant proportion of an economic indicator. Because the gross national income (GNI) adds financial flows to the GDP, the $\mathrm{GNI}_{\text {Cap }}$ makes the better indicator of national wealth. Therefore, the mean ratio between minimum wages and the $\mathrm{GNI}_{\text {Cap }}$ in the chosen benchmark countries is selected as the best ratio. However, statistics on international minimum wages are complex. There are great differences in data and minimum wage systems. Table 2 shows a survey of these differences including how this paper deals these.

OECD and ILO data were used in preference, but because these databases are not complete, additional data were obtained from Wage Indicator Foundation (2013) and Minimumwage.org (2013). The data for the benchmark group that determines the proportion are all from OECD or ILO databases. In our benchmark group of countries, the average proportion of the minimum wage relative to $\mathrm{GNI}_{\text {Cap }}$ in 2011 was $44.4 \%$.

Appendix 1 (Electronic Supplementary Material) presents for 183 countries the proposed fair minimum wages for 2011 in US\$ PPP, calculated as $44.4 \%$ of GNI $\mathrm{Gap}_{\text {Cap }}$ expressed in 2011 US\$ PPP, bottom cutoff by the above proposed absolute minimum wage of \$ 1547 in 2005 PPP US\$, which remains, as
Fig. 2 The Preston curve: life expectancy (CIA factbook 2012, data on 2011) versus GDP per capita (World Bank 2011). The dotted lines are the linear trendlines for GDP/cap $=\$ 3000$ $\$ 30,000$ and from $\$ 30,000$ up, crossing at a GDP/cap of about $\$ 30,000$

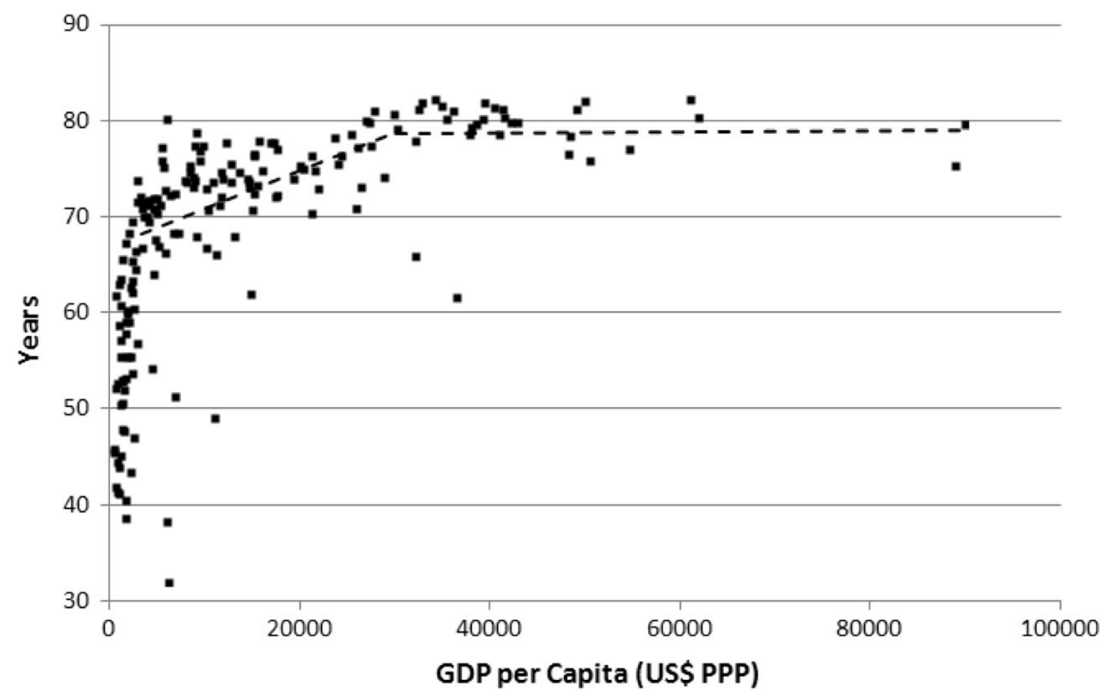


Fig. 3 The Preston curve, enlarged for GDP/Cap $<10,000$ : life expectancy (CIA factbook 2012, data on 2011) versus GDP per capita (World Bank 2011). The dotted lines are the linear trendlines for GDP/cap $=\$ 0$ $\$ 3000$ and $\$ 3000-\$ 10,000$, crossing at a GDP/cap of about $\$ 3500$

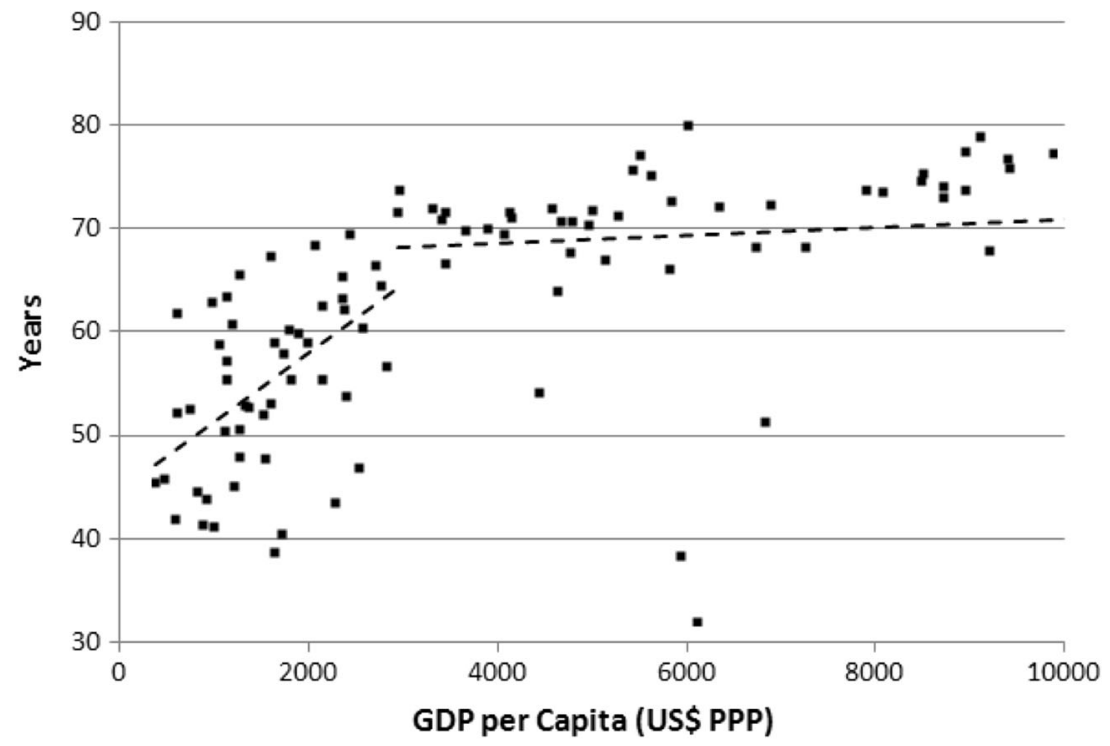

US\$, the same for 2011. In addition, the Appendix 1 (Electronic Supplementary Material) lists the statutory minimum wage in 2011 US\$ PPP and the ratio between the statutory minimum wage and the proposed fair minimum wage.

\subsection{Preventative measures and converting into ESCUs (steps 3, 4 and 5)}

For the determination of the (un)sustainability score in preventative costs-based SLCA, one more parameter must be determined: the cost distance between the actual sub-fair wage and the fair minimum wage, the ESCUs. With a known target for the fair minimum wage for every country, there is only one possible preventative measure against underpayment: raise the actual wages of all sub-fair paid people involved in activities related to the product, to the target. But what level of actual wages must be used?
Not many data are available on actual sub-minimum wages because many of these are not compliant with national legislation and try to be invisible. An exception is the work of Wageindicator, an organization that, in cooperation with Dutch and local universities, provides valuable data on actual wages all over the world. In ten reports on wages in developing countries (Benin, Costa Rica, Ghana, Guinea, Honduras, Indonesia, Madagascar, Sri Lanka, Ruanda and Uganda), Wageindicator reports that an average of $34 \%$ of the investigated wages were below minimum wage (Cambodia Institute of Development Study 2011; Besamusca et al. 2012a, b, c, 2013a, b, c, d; Wage Indicator 2013; Perenelli and Beker 2011).

The lowest reported actual wages per country (medians for lowest-paid groups) showed great variation, with an average of about $43 \%$ of the national minimum wage, and the very lowest reported (Indonesia) was only $6 \%$ of the local minimum wage, indicating that exploitation of the necessitous almost goes to the zero limit.
Fig. 4 Happy life years (Veenhoven 2012, data on 2011) versus GDP per capita (World Bank 2011). The dotted lines are the linear trendlines for GDP/cap of $\$ 0-\$ 30,000$ and from $\$ 30,000$ up, crossing at a GP/cap of about $\$ 25,000$

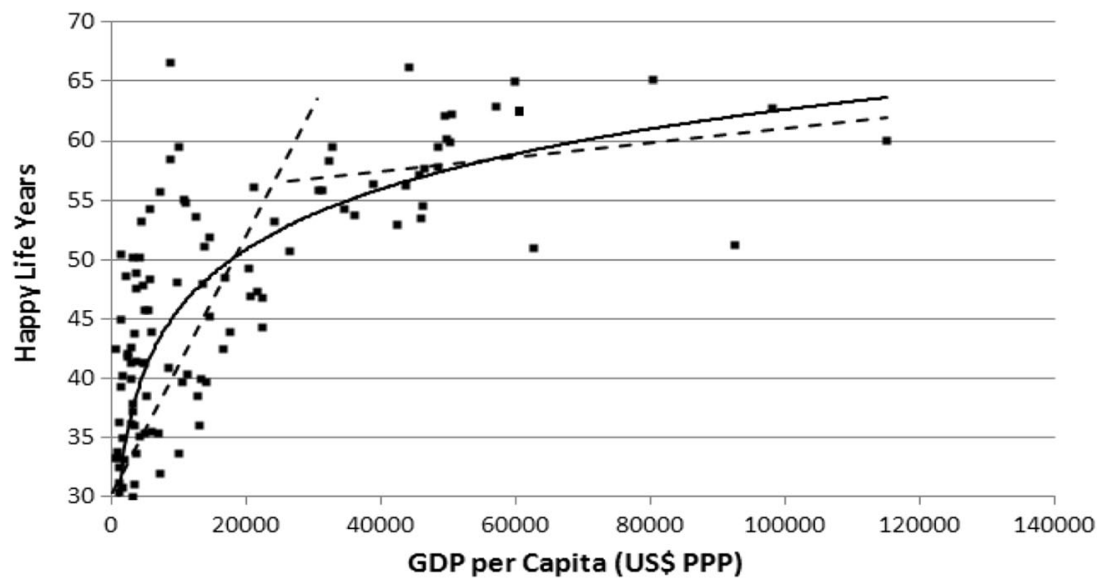


Table 2 Methods used by different countries to set and describe their minimum wage systems

\begin{tabular}{|c|c|}
\hline Differences by & Relevance and position \\
\hline Currency & All presented data are in US\$ PPP 2011 \\
\hline $\begin{array}{l}\text { Defined period and differences in working hours } \\
\text { and days the data refer to }\end{array}$ & $\begin{array}{l}\text { The MW may be set per year/month/day or hour. In addition. yearly, monthly and weekly data vary } \\
\text { greatly on the working hours or days they refer to. Where yearly MWs were set and reported, as } \\
\text { for almost all OECD data, these were used. Hourly, daily and monthly MWs were normalized to } \\
\text { yearly MWs using the factors of } 1864 \mathrm{~h}, 233 \text { days and } 12 \text { month per year. Where data on several } \\
\text { periods were available, the highest result was used. }\end{array}$ \\
\hline $\begin{array}{l}\text { Rural or municipal MWs, regionally fixed MWs, } \\
\text { special MWs for agriculture }\end{array}$ & $\begin{array}{l}\text { Such differences do not occur in the benchmark group. For other countries, the lowest MW in the } \\
\text { country was used. }\end{array}$ \\
\hline $\begin{array}{l}\text { Industry branch, skills or education level or } \\
\text { private/public employment }\end{array}$ & $\begin{array}{l}\text { Such differences do not occur in the benchmark group. For other countries, the lowest MW in the } \\
\text { country was used. }\end{array}$ \\
\hline Number of employees & $\begin{array}{l}\text { Such differences do not occur in the benchmark group. For other countries, the lowest MW in the } \\
\text { country was used. }\end{array}$ \\
\hline $\begin{array}{l}\text { Years of employment or temporary, permanent } \\
\text { or probationary contracts }\end{array}$ & The lowest MW in the country was used. \\
\hline Age & $\begin{array}{l}\text { Almost all countries have a system for lower wages for young people. The Oiconomy standard } \\
\text { follows the ILO conventions. This paper only considers minimum wages for adults. The adult } \\
\text { threshold varies per country (ILO 1992); this paper does not address reductions for young people } \\
\text { and apprentices. }\end{array}$ \\
\hline Exemptions & $\begin{array}{l}\text { Some low-income countries have exemptions from standard MWs for domestic work and jobs only } \\
\text { for watching premises. Because these jobs often aim at not much more than community } \\
\text { involvement, the MWs of these exemptions were not considered the lowest MW. }\end{array}$ \\
\hline
\end{tabular}

$M W$ minimum wage

Interestingly, the same reports also demonstrate that the lowest wages are not paid by multinationals, but by small local companies. This however does not exclude the possibility that local companies are used by multinationals and that involved products reach Oiconomy consumers.

Figure 5 shows the actual to fair minimum wage ratio, the statutory minimum wage percentage of our calculated fair minimum wage, for all countries with a statutory minimum wage. The graph shows that the complete range between 0 and 1 occurs and that all benchmark group countries have a ratio of over 0.6. Because the fair minimum wage was calculated from the average minimum wage $/\left(\mathrm{GNI}_{\mathrm{Cap}}\right)$ ratio of the benchmark group countries, not all countries of this group have a fair minimum wage. The (un)sustainability measure in preventative costs-based SLCA is equal to the costs involved to raise all wages of the people involved in the product life cycle to the level of the fair minimum wage. In most types of LCA, these data will be very hard to collect and verify. In the Oiconomy system, however, ESCUs are determined by every actor in the supply chain and verified in a certification system, which also verifies the actor's governance. We propose the following procedure: If a supply chain actor cannot demonstrate good
Fig. 5 Actual minimum wage to fair minimum wage ratio in percentages. Minimum wages obtained most from OECDStat 2012, data on 2011 and ILO Ilostat 2012, data on 2011 that were not available from minimum-wage.org and Wageindicator and, for Bangladesh and Taiwan, from Fairwear and Taiwan Congress Library

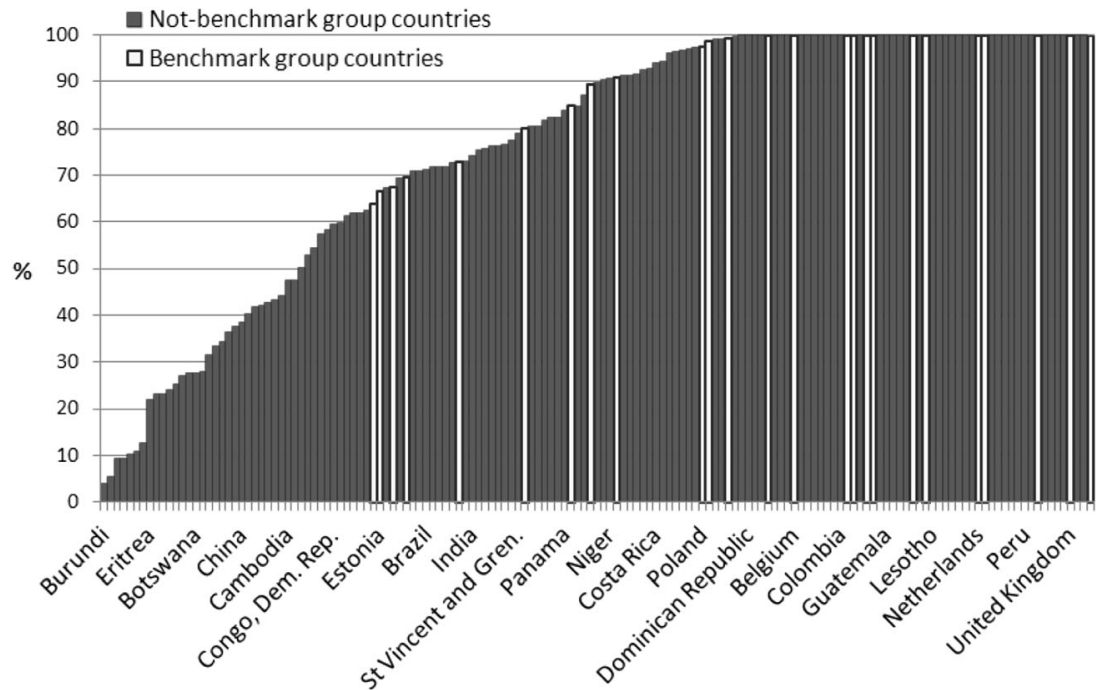


governance on wages, ESCUs are allocated equal to the difference between the actual wage and the fair minimum wage. If the actual wage is unknown, or unreliable because of bad governance, the worst case value needs to be used. Without an objectively determined worst case in the relevant country, such as by Wageindicator, we propose to assume the zero level.

\section{Discussion and conclusions}

In this article, based on ILO standards, the \$2 World Bank moderate poverty line, and the average practices in a benchmark of the $20 \%$ top performing countries in the Sustainable Society Index Human Wellbeing, a method was developed for the determination of a fair minimum wage standard. This resulted in a proposal for a fair minimum wage of a relative measure of $44.4 \%$ of the $\mathrm{GNI}_{\text {Cap }}$, bottom cutoff for the lowest-income countries by an absolute fair minimum wage (AMW) of $\$ 1547$ (PPP) per year and $\$ 0.830$ (PPP) per hour. The method and the proposed fair minimum wage are primarily intended for the determination of the marginal preventative costs for the issue of unfair prices for labour in preventative costs-based SLCA but can also be used as a PRP in SLCA in general.

Although currently fair trade products are common in the market, there is no agreed standard for a fair minimum wage. Therefore, we also suggest that the here proposed fair minimum standard can be directly used for fair trade purposes.

Investigating alternative methods for justification of our proposed $\$ 1547$ for the AMW, a striking match of $\$ 1495$ was found if the AMW would have been derived from the Preston curve kink point. However, the location of that kink point requires further discussion. Our own analyses demonstrated rather 2 kink points than 1, at a GDP/Cap of $\$ 3500$ and of $\$ 30,000$. If instead of life years, happy life years are plotted against the GDP/Cap, we find a much slower rise of the curve and a possible kink point at about $\$ 25,000$, but we also find a small group of countries having reached a high score of happy life years at much lower levels of $\$ 5000-\$ 15,000$. Quite commonly in impact-based ELCA and SLCA, health, for which LE is an indicator, is taken as an important endpoint indicator (Jolliet et al. 2004). We demonstrated that just taking a slightly different, but very justifiable, endpoint, the results are hugely different.

What are the implications for our proposal? Our proposed AMW was derived from the World Bank \$2 moderate poverty line, which is the average living wage in the world's 75 poorest countries. The living wage is based on a basket of basic needs. It tells little about happiness. Where the original Preston curve finds its major rise below a GDP/Cap of $\$ 3000$, it takes up to $\$ 25,000$ to get to high happy life year scores. In addition, after the first kink point, also life years slowly keep rising to about $\$ 30,000$.

So, not surprisingly, the World Bank $\$ 2$ poverty line only takes countries to the first LE kink point, the living wage level. But for global country-level equality in life years and happy life years, far higher incomes are required. However, in our proposed system, if a country's income rises above the cutoff point, the relative system applies, resulting in a higher fair minimum wage. Therefore, we conclude that our proposed AMW is justifiable, but does not represent full equality in human wellbeing.

The proposed proportion for the relative system is justified by the high development of the selected benchmark group of countries.

Lastly, we like to discuss the validity and limitations of our methods and data.

Minimum wages have been set by the majority of countries, but what these include may differ. Although the data used in this investigation are from World Bank and IMF databases, taxation systems and other provisions differ too much to be sure that the minimum wages of all different countries have exactly the same consequences for the workers.

Trusting World Bank and IMF data screening, in this investigation, these differences were neglected. The data as presented in Appendix 1 (Electronic Supplementary Material) are indicative and must be interpreted as gross wages, including health care, pension schemes, insurances, education and tax.

Our proposed fair wages are based on the practices of the top $20 \%$ performers in the SSI HW. In time, the composition of countries in this index will change, as will the minimum wages in these countries.

The changes in the minimum wages are limited, in OECD countries to an average $1.5 \%$ growth per year (OECD Stat Extraxts 2012). The index however demonstrates greater changes. In this paper, we have used the top $20 \%$ from 2012 (van de Kerk and Manuel 2012), including the USA. In 2014, however, the USA dropped out of the top $20 \%$. Other choices that need discussion are our fairly wide choice of using the top $20 \%$ and of using simple country averages instead. Therefore, Table 1 presents the results for some alternative choices.

From this table, we observe that the $\mathrm{AMW}_{\mathrm{Y}}$ hardly changes if calculated for the top $15 \%$ or $10 \%$ of countries, and for 2012 and 2014, even if calculated as the population weighted average. Even if calculated using another index, the UNDP Human Development Index 2013, the $\mathrm{AMW}_{\mathrm{Y}}$ remains constant. The reason is that the ratio between life expectancy and working years, the only index dependent variable in our method for the AMW, is fairly constant.

But also, the more politically influenced $\mathrm{MW} / \mathrm{GNI}_{\text {cap }}$ ratio remains stable in most of these alternatives. Only if calculated as population-weighted averages, we see not only lower ratios but also greater variation between the years and with HDI- 
derived ratios, which are mainly caused by in- or excluding the highly populated USA.

The authors of this paper propose to use the difference between the actual wages and the here proposed fair minimum wages as an indicator of (un)sustainability in SLCA. However, that is only possible if a practitioner has either complete own control over the supply chain of a product or by using a certification-based LCA system, such as the Oiconomy system, in which every actor in the supply chain determines and transfers uniformly measured and verifiable data through the supply chain.

Open Access This article is distributed under the terms of the Creative Commons Attribution 4.0 International License (http:// creativecommons.org/licenses/by/4.0/), which permits unrestricted use, distribution, and reproduction in any medium, provided you give appropriate credit to the original author(s) and the source, provide a link to the Creative Commons license, and indicate if changes were made.

\section{References}

Anker R (2006a) Living wages around the world: a new methodology and internationally comparable estimates. Int Labour Rev 145(4): 309-338

Anker R (2006b) Poverty lines around the world: a new methodology and internationally comparable estimates. Int Labour Rev 145(4):179 307

Anker R (2011) Conditions of work and employment programme estimating a living wage: a methodological review. Int Labour Off 29: $1-126$

Atkinson AB, Marlier E, Nolan B (2004) Indicators and targets for social inclusion in the European Union. J Common Mark Stud 42(1):4775

Belser P, Sobeck K (2012) At what level should countries set their minimum wages? Int J Labour Res 4(1):105-128

Besamusca J, Palma SI, Arenas LE et al (2012a) Wages in Honduras. WageIndicator Data Report, pp 1-20

Besamusca J, Palma SI, Arenas LE (2012b) Wages in El Salvador. Wage Indicator Data Report, pp 1-23

Besamusca J, Tijdens K et al (2012c) Wages in Uganda. WageIndicator Data Report, pp 1-21

Besamusca J, Tijdens K, Alinsato AS et al (2013a) Wages in Benin. Wage Indicator Data Report, pp 1-19

Besamusca J, Tijdens K, Tingum EN, Diallo H (2013b) Wages in Guinea. WageIndicator Data Report 2012, pp 1-20

Besamusca J, Tijdens K, Tingum EN, Ravelosoa R (2013c) Wages in Madagascar. WageIndicator Data Report 2012, pp 1-19

Besamusca J, Tijdens K, Mbassana ME et al (2013d) Wages in Rwanda. Wage Indicator Data Report, pp 1-20

Bhattacharjee A, Roy P (2012) Asia floor wage and global industrial collective bargaining. Int J Labour Res 4(1):67-83

Bocoum I, Macombe C, Revéret J-P (2015) Anticipating impacts on health based on changes in income inequality caused by life cycles. Int J Life Cycle Assess 20(3):405-417

Boeri T (2009) Setting the minimum wage. IZA Discuss Pap 4335:1-28
Brenner $\mathrm{M}$ et al (2002) Defining and measuring a global living wage: theoretical and conceptual issues. In: Global Labor Standards and Living Wages Conference, Massachusetts. Amherst, pp 1-22

Cambodia Institute of Development Study (2011) Minimum wage compliance report Cambodia. Wageindicator.org, pp 1-14

Chen S, Ravallion M (2008) The developing world is poorer than we thought, but no less successful in the fight against poverty. World Bank Pol Res Work Pap 4703:1-52

Chen S, Ravallion M (2012) More relatively-poor people in a less absolutely-poor world. World Bank Pol Res Work Pap 6114:1-40

CIA factbook (2012) Avaialable at https://www.cia.gov/library/ publications/the-world-factbook. Accessed 1 Nov 2012

Council of the European Union (2004) Joint report by the Commission and the Council on social inclusion, no. 7101/04, Bruxelles

Croes PR, Vermeulen WJV (2015) Comprehensive life cycle assessment by transferring of preventative costs in the supply chain of products. A first draft of the Oiconomy system. J Clean Prod 102:177-187

Croes PR, Vermeulen WJV (2016) In search of income reference points for SLCA using a country level sustainability benchmark (part 1): fair inequality. A contribution to the Oiconomy Project. Int J Life Cycle Assess. doi:10.1007/s11367-015-1018-0

Deaton A (2003) Health, inequality, and economic development. J Econ Lit XLI pp. 113-158

Edin K, Lein L (1997) Work, welfare, and single mothers' economic survival strategies. Am Sociol Rev 62(2):253-256

Edward P (2006) The ethical poverty line: a moral quantification of absolute poverty. Third World Q 27(2):377-393

Ethical Trading Initiative (2012) The ETI base code, pp 1-3. Available at: http://www.ethicaltrade.org/eti-base-code

ETUC (2012) Solidarity in the crisis and beyond: towards a coordinated European trade union approach to tackling social dumping. ETUC Winter School, pp 7-8

Fair Labor Association (2011) FLA workplace code of conduct and compliance benchmarks, pp 1-40. Available at: http://www.fairlabor. org/sites/default/files/fla_complete_code_and_benchmarks.pdf

FAO, WHO \& UNU (2001) Human energy requirements. Report of a Joint FAO/WHO/UNU Expert Consultation, Rome

Feschet $\mathrm{P}$ et al (2013) Social impact assessment in LCA using the Preston pathway: the case of banana industry in Cameroon. Int J Life Cycle Assess 18:490-503

Gentilini U, Sumner A (2012) What do national poverty lines tell us about global poverty? IDS Working Paper (392):1-48

Global Social Compliance Programme (2010) Global Social Compliance Programme reference code

Haughton JH, Khandker SR (2009) Handbook on poverty and inequality. World Bank, Washington

Hsu C, Wang S, Hu AH (2013) Development of a new methodology for impact assessment of SLCA. In: 20th CIRP International Conference on Life Cycle Engineering, Singapore, 2013. Singapore, pp. 2-6

ILO (1935) C047-Forty-Hour Week Convention. NORMLEX information system on International Labour Standards, No. 047

ILO (1944) Preamble ILO Constitution. NORMLEX information system on International Labour Standards

ILO (1962) R116 - Reduction of Hours of Work Recommendation. NORMLEX information system on International Labour Standards, No. 116

ILO (1970) C132-Holidays with Pay Convention (Revised). NORMLEX Information System on International Labour Standards, No. 132

ILO (1992) Minimum wages. Wage-fixing machinery, application and supervision. In: International Labour Conference, 79th Session. Geneva, pp 1-213

ILO (2008) ILO declaration on social justice for a fair globalization. pp. $1-22$ 
ILO (2010) Global wage report 2010/11—wage policies in times of crisis, Geneva

ILO Ilostat (2012) Ilostat. Available at http://www.ilo.org/ilostat. Accessed 1 Nov 2011

International Training Centre of the ILO (2008) Guide to international labour standards, Turin

Jolliet $\mathrm{O}$ et al (2004) UNEP/SETAC life cycle initiative. Int J Life Cycle Assess 9(6):394-404

Labour Behind the Label (2013) The right to a living wage, p. 1. Available at: http://www.labourbehindthelabel.org

Luce S (2012) Living wage policies and campaigns: lessons from the United States. Int J Labour Res 4(1):1-26

Mercer (2011) Employee holiday entitlements around the world. Mercer. Available at: http://www.mercer.com/press-releases/holidayentitlements-around-the-world

Merk J (2009) Stitching a decent wage acrosss borders. The Asia Floor Wage Proposal, New Delhi

Minimum-wage.org (2013) minimum-wage.org. Available at: www. minimum-wage.org

Neugebauer S et al (2014) Impact pathways to address social well-being and social justice in SLCA-fair wage and level of education. Sustainability 6(8):4839-4857

Neumark D, Wascher W (2007) Minimum wages and employment, Bonn

Norris GA (2006) Social impacts in product life cycles. Towards life cycle attribute assessment. Int J Life Cycle Assess 1(1):97-104

OECD Stat Extraxts (2012) Average annual hours actually worked per worker. Available at: http://stats.oecd.org/Index.aspx? DataSetCode $=$ ANHRS

Parent J, Cucuzzella C, Revéret J-P (2010) Impact assessment in SLCA: sorting the SLCIA methods according to their outcomes. Int J Life Cycle Assess 15(2):164-171

Perenelli B and Beker VA (2011) Minimum wage non compliance in Indonesia. www.wageindicator.org, pp 1-17

Preston SH (1975) The changing relation between mortality and level of economic development. Pop Stud 29(2):231-248

Pritchett L (2006) Who is not poor? Dreaming of a world truly free of poverty. World Bank Res Obs 21(1):1-23

Pritchett L, Viarengo M (2010) Explaining the cross-national time series variation in life expectancy: income, women's education shifts and what else? Hum Dev Res Pap 31:67

Rani U, Belser P (2012) The effectiveness of minimum wages in developing countries: the case of India. Int J Labour Res 4(1):45-66

Ravallion M (1992) Poverty comparisons: a guide to concepts and methods. Living Stand Meas Study Work Pap 88:1-125
Ravallion M (2010) Poverty lines across the world. World Bank Policy Res Work Pap 5284:1-38

Ravallion M (2011) On multidimensional indices of poverty. World Bank Policy Res Work Pap 5580:1-20

Ravallion M, Chen S, Sangraula P (2008) Dollar a day revisited, Washington DC

Rutkowski J (2003) The minimum wage: curse or cure? The World Bank, pp 1-15

Social Accountability International (2008) Social accountability 8000, New York

Sumner A (2010) Global poverty and the new bottom billion: what if three-quarters of the world's poor live in middle-income countries? Inst Dev Stud 349:1-43

Sumner A (2012) Where do the world's poor live? A New Update, Brighton

SweatFree Communities (2014) Non-poverty wages for countries around the world, pp 1-3. Available at: http://www.sweatfree.org/ nonpovertywages

UN General Assembly (1948) Universal declaration of human rights. United Nations, pp 1-6

UNEP \& SETAC (2009) UNEP guidelines for social life cycle assessment of products

United Nations (2007) Indicators of sustainable development: guidelines and methodologies. In: United Nations. New York

van de Kerk G, Manuel AR (2012) Sustainable Society Index SSI-2012. In: Sustainable Society Foundation. Uitgeverij de Vijver, The Hague, The Netherlands

Veenhoven R (2012) World database of happiness. Erasmus University, Rotterdam, The Netherlands. Available at: http://www1.eur.nl/fsw/ happiness/index.html

Voedingscentrum (2014) Dutch Nutrition Centre. Energie. Available at: http://www.voedingscentrum.nl/encyclopedie/energie.aspx

Vogtländer JG, Brezet HC, Hendriks CF (2000) The virtual eco-costs' 99. Int J Life Cycle Assess 5(6):1-10

Wage Indicator Foundation (2013) www.wageindicator.org. Available at: www.wageindicator.org

Wilkinson RG, Pickett KE (2009) Income inequality and social dysfunction. Annu Rev Sociol 35(1):493-511

World Bank (2005) Introduction to poverty analyses. Washington DC

World Bank (2011) World Bank Data. Available at: http://data. worldbank.org/. Accessed 1 Nov 2014

Wu J, Liu E (1999) Minimum Wage Systems. Legislative Council of the Hong Kong special legislative region of the People's Republic of China, RP08/98-99, pp 1-104 